\title{
PERBEDAAN PENINGKATAN KEMAMPUAN PEMECAHAN MASALAH MATEMATIS SISWA YANG MEMPEROLEH MODEL PEMBELAJARAN KOOPERATIF TIPE TWO STAY-TWO STRAY (TS-TS) DAN MODEL PEMBELAJARAN PROBLEM BASED LEARNING (PBL) DI KELAS VII SMP ISLAM AL-FALAH JAMBI
}

\author{
Putri Mulyani $^{1}$, Zulyadaini $^{2}$, Eni Defitriani ${ }^{3}$ \\ Program Studi Pendidikan Matematika, FKIP, Universitas Batanghari ${ }^{1,2,3}$ \\ Jl. Slamet Riyadi No.1 Broni Jambi \\ Email : eni.defitriani@unbari.ac.id
}

\begin{abstract}
ABSTRAK
Penelitian ini dilatarbelakangi oleh rendahnya kemampuan pemecahan masalah matematika siswa kelas tujuh SMP Islam Al-Falah Jambi. Penelitian ini adalah penelitian eksperimental semu dengan desain Nonequivalent Pretest-Posttest Control Group Design dan pola yang semua siswa Sekolah Menengah Islam Al-Falah pada tahun akademik 2017/2018. Pengambilan sampel menggunakan purposive sampling, yaitu sampel yang terdiri dari tiga kelas yaitu kelas VII.1, VII.2 dan VII.4 dimana sampel yang diberikan berbeda. Instrumen yang digunakan dalam penelitian ini adalah bahan ajar dan tes kemampuan solusi matematika. Data penelitian dianalisis menggunakan hasil statistik non parametrik Kruskal Wallis H.. Hasil penelitian menunjukkan bahwa terdapat perbedaan yang dihadapi oleh siswa yang belajar dengan dua tipe Two Stay-Two Stray (TS-TS), model pembelajaran Problem Based Learning (PBL), dan model pembelajaran konvensional. Setelah lebih lanjut menggunakan tes Games-Howell, perbedaan dalam kelas TS-TS dan kelas PBL kemudian menjadi kelas PBL dan kelas konvensional.
\end{abstract}

\section{Kata kunci:}

Kemampuan pemecahan masalah matematika, Two stay-Two Stray (TS-TS), Problem Based Learning (PBL).

\begin{abstract}
This research was motivated by the low mathematical problem-solving ability of the seventh grade students of Al-Falah Islamic Junior High School Jambi. This research is a quasi-experimental study with Nonequivalent Pretest-Posttest Control Group Design design and a pattern that is all students of Al-Falah Islamic Middle School in the academic year 2017/2018. Sampling used purposive sampling, which is a sample consisting of three classes namely class VII.1, VII.2 and VII.4 where the given sample is different. The instruments used in this study are teaching materials and mathematical solution ability tests. The research data were analyzed using non parametric Kruskal Wallis $H$. statistical results. The results showed that there were differences faced by students who studied with two types of Two Stay-Two Stray (TS-TS), Problem Based Learning (PBL) learning models, and models conventional learning. After further using the Games-Howell test, the differences in the TS-TS class and PBL class then become PBL classes and Conventional classes.
\end{abstract}

Keywords:

Mathematical problem solving ability, Two stay-Two Stray (TS-TS), Problem Based Learning $(P B L)$.

\section{PENDAHULUAN}

Matematika merupakan salah satu mata pelajaran yang dipelajari dari sekolah dasar hingga sekolah lanjutan.
Tidak hanya itu, matematika juga sering digunakan dalam kehidupan sehari-hari seperti melakukan transaksi jual beli, menghitung laba rugi dan lain 


\section{$\pi$ (Phi)}

sebagainya. Matematika perlu diberikan kepada semua peserta didik mulai dari sekolah dasar untuk membekali mereka dengan kemampuan berpikir logis, analitis, sistematis, kritis dan kreatif serta kemampuan dalam bekerja sama. Matematika mempunyai peranan yang penting untuk dimengerti siswa.

Menurut Depdiknas (Shadiq, 2014) ada lima tujuan pembelajaran matematika yang harus dicapai para siswa dari selama proses pembelajaran di kelas matematika, yaitu; (1) Memahami konsep matematika, menjelaskan keterkaitan antar konsep dan mengaplikasikan konsep atau algoritma, secara luwes, akurat, efisien dan tepat dalam pemecahan masalah; (2) Menggunakan penalaran pada pola dan sifat, melakukan manipulasi matematika dalam membuat generalisasi, menyusun bukti, atau menjelaskan gagasan dan pernyataan matematika; (3) Memecahkan masalah yang meliputi kemampuan memahami masalah, merancang model matematika, menyelesaikan model dan menafsirkan solusi yang diperoleh; (4) Mengomunikasikan gagasan dengan simbol, tabel, diagram, atau media lain untuk memperjelas keadaan atau masalah; (5) Memiliki sikap menghargai kegunaan matematika dalam kehidupan, yaitu rasa ingin tahu, perhatian, dan minat dalam mempelajari matematika, serta sikap ulet dan percaya diri dalam pemecahan masalah.

Salah satu tujuan pembelajaran matematika di atas adalah kemampuan pemecahan masalah yang terdapat pada poin ke tiga. Kemampuan Pemecahan masalah adalah suatu pemikiran yang terarah secara langsung untuk menemukan suatu solusi/jalan keluar untuk suatu masalah yang spesifik (Solso dkk,2007).
Disamping itu, pemecahan masalah matematika bagi para siswa juga mempunyai peranan dan manfaat yang besar. Peranan dan manfaat tersebut menurut Roebyanto dan Harmini (2017) adalah sebagai berikut: (a) Membantu siswa dalam hal menyelesaikan masalah di kehidupan sehari-hari secara kreatif dan efektif; (b) Menstimulasi dan membantu pemikiran siswa dalam menemukan strategi pemecahan masalah untuk masalah atau situasi baru yang dihadapi siswa; (c) Mengembangkan, memperkuat, dan mengingat kembali konsep-konsep matematika dan keterampilan procedural yang telah dimiliki siswa; (d) Mengembangkan naluri penemuan siswa; (e) Memunculkan kemampuan imaginasi dan kreasi siswa berdasar pada ide-ide dalam masalah matematika.

Dilihat dari tujuan pembelajaran matematika serta peranan dan manfaat maka kemampuan pemecahan masalah merupakan kemampuan yang penting bagi siswa, karena puncak keberhasilan pembelajaran matematika adalah ketika siswa mampu memecahkan masalah yang dihadapi. Hal ini senada dengan pendapat Hendriana dkk (2017) yang mengemukakan pada dasarnya kemampuan pemecahan masalah matematis merupakan suatu kemampuan yang penting dan perlu dikuasai oleh siswa yang belajar matematika. Salah satu yang mendasari pernyataan tersebut adalah pemecahan masalah matematik merupakan kemampuan yang tercantum dalam kurikulum dan tujuan pembelajaran matematika.

Namun

kenyataannya, kemampuan pemecahan masalah matematis masih rendah berdasarkan hasil observasi di SMP Islam Al-Falah 


\section{$\pi$ (Phi)}

Jambi diketahui bahwa siswa masih kesulitan dalam memahami materi yang disampaikan oleh guru, kegiatan belajar di dalam kelas masih mengandalkan ceramah. Selain itu siswa juga terlihat kesulitan dalam menyelesaikan soalsoal cerita dikarenakan masih kurangnya pemahaman siswa pada soal tersebut.

Berdasarkan permasalahan diatas ada beberapa solusi untuk mengatasi rendahnya kemampuan pemecahan masalah matematis, salah satunya adalah menggunakan model pembelajaran. Hal ini sesuai dengan pendapat Aunurrahman (2011) keberhasilan proses pembelajaran tidak terlepas dari guru mengembangkan model-model pembelajaran yang berorientasi pada peningkatan intensitas keterlibatan siswa secara efektif di dalam proses pembelajaran. Menurut Saraswati (Suraji dan Sari, 2017) salah satu model pembelajaran yang bisa diterapkan untuk meningkatkan pemecahan masalah matematis siswa adalah model pembelajaran kooperatif tipe Two Stay-Two Stray(TS-TS). Dengan adanya interaksi positif antar kelompok, maka akan melatih kemampuan siswa dalam pemecahan masalah, dan memacu terbentuknya ide baru serta memperkaya perkembangan intelektual siswa.

Selain dari model pembelajaran kooperatif tipe Two Stay-Two Stray(TSTS), model lain yang dapat meningkatkan kemampuan pemecahan masalah adalah model pembelajaran Problem Based Learning(PBL). Hal ini sesuai dengan pendapat Ward (Lestari dan Yudhanegara, 2015) yang menemukakan, bahwa PBL adalah suatu model pembelajaran yang melibatkan siswa untuk menyelesaikan suatu masalah melalui tahap-tahap metode ilmiah sehingga siswa dapat mempelajari pengetahuan yang berhubungan dengan masalah tersebut sekaligus memiliki keterampilan untuk menyelesaikan masalah. Menurut Shoimin (2014) model pembelajaran Problem Based Learning(PBL) dapat melatih dan mengembangkan kemampuan untuk menyelesaikan masalah yang berorientasi pada masalah autentik dari kehidupan aktual siswa, untuk merangsang kemampuan berfikir tingkat tinggi.

Dengan demikian, penulis tertarik untuk melakukan penelitian dengan judul "Perbedaan Peningkatan Kemampuan Pemecahan Masalah Matematis Siswa yang Memperoleh Model Pembelajaran Kooperatif tipe Two Stay-Two Stray (TS-TS) dan Model Pembelajaran Problem Based Learning(PBL) di Kelas VII SMP Islam Al-Falah Jambi”.

\section{METODE PENELITIAN}

Penelitian ini termasuk dalam penelitian quasi eksperimen. Menurut Lestari dan Yudhanegara (2015) bahwa quasi eksperimen paling mungkin untuk dilakukan dalam penelitian khususnya terkait pendidikan/pembelajaran.

Penulis melakukan penelitian di tiga kelas dengan dua kelas diberikan perlakuan sebagai kelas eksperimen dan satu kelas diberikan perlakuan sebagai kelas kontrol. Kelas eksperimen I diajarkan dengan model pembelajaran Kooperatif tipe Two Stay-Two Stray (TS-TS)dan kelas eksperimen II diajarkan dengan model pembelajaran Problem Based Learning (PBL) serta kelas kontrol diajarkan dengan model pembelajaran konvensional. Desain Penelitian yang digunakan adalah The Nonequivalent Pretest-Postest Control Group Design. 


\section{$\pi$ (Phi)}

Desain ini hampir sama dengan the randomized pretest-posttest control group design, di mana sebelum dilakukan penelitian ketiga kelompok diberi pretes untuk mengetahui keadaan awalnya. Selama penelitian berlangsung kelompok pertama diberi perlakuan berupa pembelajaran dengan model Kooperatif tipe Two Stay-Two Stray (TS-TS) dan kelompok kedua diberi perlakuan berupa pembelajaran dengan model Problem Based Learning (PBL), sedangkan kelompok ketiga tidak diberi perlakuan. kelompok yang diberi perlakuan dijadikan kelompok eksperimen dan kelompok yang tidak diberi perlakuan adalah kelompok kontrol. Selanjutnya diakhir penelitian, ketiga kelompok diberi postes untuk melihat bagaimana hasilnya (Lestari dan Yudhanegara, 2015:138).

Desain penelitian ini dapat diilustrasikan sebagai berikut:

\begin{tabular}{|lll|}
\hline $\mathbf{O}$ & $\mathbf{X}_{1}$ & $\mathbf{O}$ \\
$\mathbf{O}^{-}$ & $\mathbf{X}_{\mathbf{2}}$ & $\mathbf{O}$ \\
$\mathbf{O}$ & & $\mathbf{O}$ \\
\hline
\end{tabular}

Keterangan:

$\mathrm{X}_{1}=$ Pembelajaran model Kooperatif tipe Two Stay-Two Stray(TS-TS)

$\mathrm{X}_{2}=$ Pembelajaran model Problem Based Learning(PBL)

$\mathrm{O}=$ Pretes/postes (variabel dependen yang diobservasi)
--.-- = Pengambilan sampel tidak dilakukan secara acak.

Penelitian ini dilakukan di kelas VII SMP Islam Al-Falah Jambi dan dilakukan pada bulan April-Mei semester genap tahun ajaran 2017/2018. Populasi dalam penelitian ini adalah seluruh siswa kelas VII SMP Islam AlFalah Jambi tahun ajaran 2017/2018 yang terdiri dari 4 kelas. Dalam penelitian ini sampel yang digunakan sebanyak tiga kelas dengan dua kelas diberikan perlakuan sebagai kelas eksperimen dan satu kelas diberikan perlakuan sebagai kelas kontrol dengan teknik purposive sampling, yaitu teknik penentuan sampel dengan pertimbangan tertentu.

\section{HASIL DAN PEMBAHASAN}

Pengolahan data dilakukan dengan menggunakan aplikasi IBM SPSS STATISTIC 20. Sebelum diberi perlakuan ketiga kelas sampel diberikan pretes tentang materi aritmatika sosial. Dalam penelitian ini pemberian pretes dilakukan untuk melihat kemampuan awal siswa dalam memecahkan masalah matematis sebelum mereka menerima materi pelajaran. Berikut ini merupakan statistik deskriptif data pretes kemampuan pemecahan masalah matematis siswa untuk ketiga kelas sampel yang disajikan pada tabel berikut.

Tabel 1. Statistik Deskriptif Data Pretes

\begin{tabular}{lccc}
\hline \multicolumn{1}{c}{ Statistik } & \multicolumn{3}{c}{ Kelas } \\
\cline { 2 - 4 } & TS-TS & PBL & Konvensional \\
\hline Ukuran Sampel & 29 & 30 & 30 \\
Rata-rata & 6,48 & 5,87 & 7,60 \\
Skor Tertinggi & 18 & 35 & 13 \\
Skor terendah & 0 & 0 & 0 \\
Simpangan baku & 4,20 & 7,57 & 3,32 \\
Varians & 17,62 & 57,29 & 11,01 \\
\hline
\end{tabular}




\section{$\pi$ (Phi)}

Berdasarkan tabel di atas dapat dilihat bahwa rata-rata skor pretes dari ketiga kelas terlihat berbeda, skor ratarata pretes tertinggi terdapat pada kelas konvensional sebesar 7,6. Tetapi, skor tertinggi terdapat pada kelas PBL sebesar 35. Simpangan baku pada kelas PBL juga lebih tinggi dibandingkan kelas TS-TS dan kelas konvensional yaitu sebesar 7,57, yang berarti skor pretes pada kelas PBL lebih beragam dibanding kelas TS-TS dan kelas konvensional.

Berdasarkan hasil uji inferensi, diperoleh bahwa data hasil pretest untuk ketiga kelas, salah satu kelas tidak berdistribusi normal, sehingga dilakukan uji Kruskal Wallis dengan taraf signifikansi $\alpha=0,05$. Dari uji tersebut diperoleh Asymp Sig. sebesar 0,037 (kurang dari 0,05) itu berarti bahwa terdapat perbedaan skor pretes kemampuan pemecahan masalah matematis siswa kelas TS-TS, kelas PBL dan kelas konvensional.

Setelah melakukan pretest, pertemuan selanjutnya adalah memberikan perlakuan pembelajaran Kelas eksperimen I diberi perlakuan model pembelajaran kooperatif tipe Two Stay-Two Stray (TS-TS), kelas eksperimen II diberi perlakuan model pembelajaran Problem Based Learning (PBL), sedangkan pada kelas kontrol memperoleh model pembelajaran konvensional. Pelaksanaan pembelajaran dilakukan sebanyak empat kali pertemuan. Setelah pelaksanaan pembelajaran selesai, maka dilakukan postes.

Oleh karena hasil pengujian terhadap data pretes menunjukkan adanya perbedaan kemampuan awal siswa, maka data yang dianalisis selanjutnya adalah data $N$-gain. Berikut adalah statistik deskriptif data $\mathrm{N}$-gain untuk ketiga kelas sampel.

Tabel 2. Statistik Deskriptif Data $N$-gain

\begin{tabular}{lccc}
\hline \multicolumn{1}{c}{ Statistik } & \multicolumn{3}{c}{ Kelas } \\
\cline { 2 - 4 } & TS-TS & PBL & Konvensional \\
\hline Ukuran Sampel & 29 & 30 & 30 \\
Rata-rata & 0,21 & 0,35 & 0,14 \\
Skor Tertinggi & 0,64 & 0,88 & 0,37 \\
Skor terendah & 0,00 & 0,06 & 0,02 \\
Simpangan baku & 0,15 & 0,22 & 0,10 \\
Varians & 0,22 & 0,48 & 0,01 \\
\hline
\end{tabular}

Berdasarkan tabel diatas ratarata skor $N$-gain terlihat berbeda, ratarata skor $N$-gain tertinggi terdapat pada kelas PBL sebesar 0,35. Selain itu, terlihat bahwa simpangan baku kelas TS-TS dan kelas PBL masing-masing sebesar 0,15 dan 0,22, sedangkan untuk kelas konvensional sebesar 0,10. Itu artinya skor $\mathrm{N}$-gain siswa kelas PBL lebih beragam dibandingkan dengan kelas TS-TS dan kelas konvensional. Dari hasil uji inferensi, diperoleh bahwa data $N$-gain berdistribusi normal dan tidak homogen, sehingga perlu dilakukan uji Kruskal Wallis dengan taraf signifikansi $\alpha=0,05$. Dari uji tersebut diperoleh nilai Sig. 0,000 ( kurang dari 0,05) ini berarti Selanjutnya, dilakukan dilakukan uji lanjut (post hoc test) menggunakan uji Games-Howell, karena data $N$-gain tidak homogen dan hasil pengujian Kruskal WallisH menunjukkan terdapat perbedaan di antara ketiga kelompok sampel. Berikut adalah tabel uji lanjut (post hoc test) Games-Howell. 
Tabel 3.Hasil Uji Lanjut Games-Howell

\begin{tabular}{ccc}
\hline Kelas & Kelas & Sig. \\
\hline TS-TS & PBL & 0,011 \\
& Konvensional & 0,093 \\
PBL & TS-TS & 0,011 \\
& Konvensional & 0,000 \\
Konvensional & TS-TS & 0,093 \\
& PBL & 0,000 \\
\hline
\end{tabular}

Dari tabel di atas dapat dijelaskan tiga hal berikut:

1. Terdapat perbedaan peningkatan kemampuan pemecahan masalah matematis siswa yang memperoleh model pembelajaran TS-TS dan model pembelajaran PBL.

2. Tidak terdapat perbedaan peningkatan kemampuan pemecahan masalah matematis siswa yang memperoleh model pembelajaran TS-TS dan model pembelajaran Konvensional.

3. Terdapat perbedaan peningkatan kemampuan pemecahan masalah matematis siswa yang memperoleh model pembelajaran PBL dan model pembelajaran Konvensional.

Berdasarkan hasil uji statistik dapat dilihat kualitas peningkatan $N$ - gain yang terdapat pada rata-rata kelas PBL sebesar 0,35 termasuk kategori sedang. Sedangkan kualitas peningkatan pada kelas TS-TS dan kelas Konvensional berturut-turut sebesar 0,21 dan 0,14 termasuk dalam kategori rendah.

Dalam pelaksanaan pembelajaran PBL pada pelajaran matematika merupakan hal baru bagi kelas VII.1 di SMP Islam Al-Falah Jambi. Hal ini membuat suasana lain dari sebelumnya, karena siswa terbiasa belajar secara konvensional. Kegiatan belajar dengan menggunakan PBL bagi siswa yang memiliki pengetahuan yang cukup luas membuat kegiatan pembelajaran lebih efektif. Hal ini dapat dilihat pada gambar berikut:

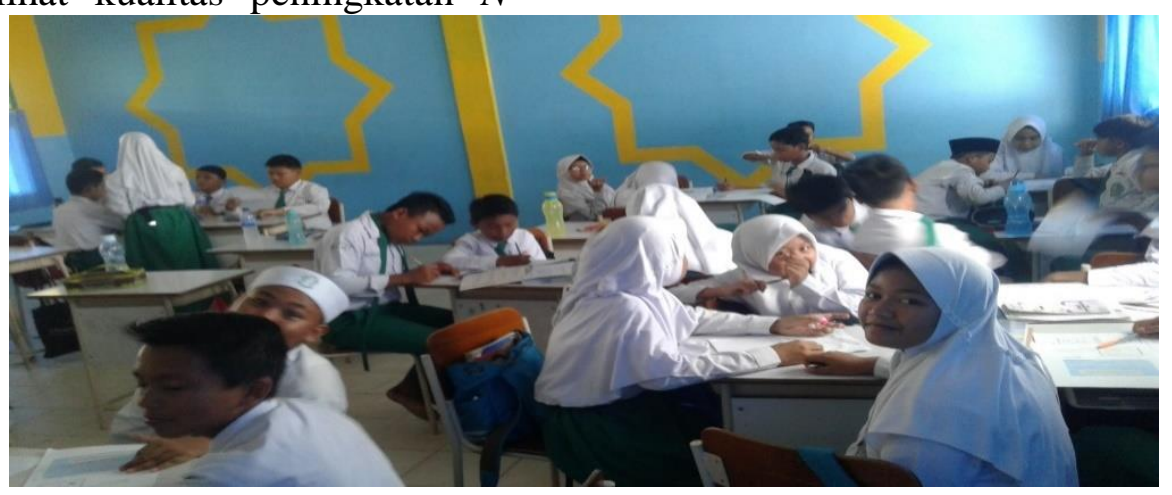

Gambar 1. Kondisi Kelas PBL

Dalam pembelajaran PBL siswa berdiskusi bersama teman-teman sekelompoknya untuk memecahkan masalah yang diberikan oleh guru. Sehingga siswa mengalami proses belajar yang bermakna dengan kelompoknya, yang akan mengembangkan kognitif siswa (Defitriani, 2015). Hasil penyelesaian 
masalah dari salah satu kelompok dapat dilihat pada gambar berikut:

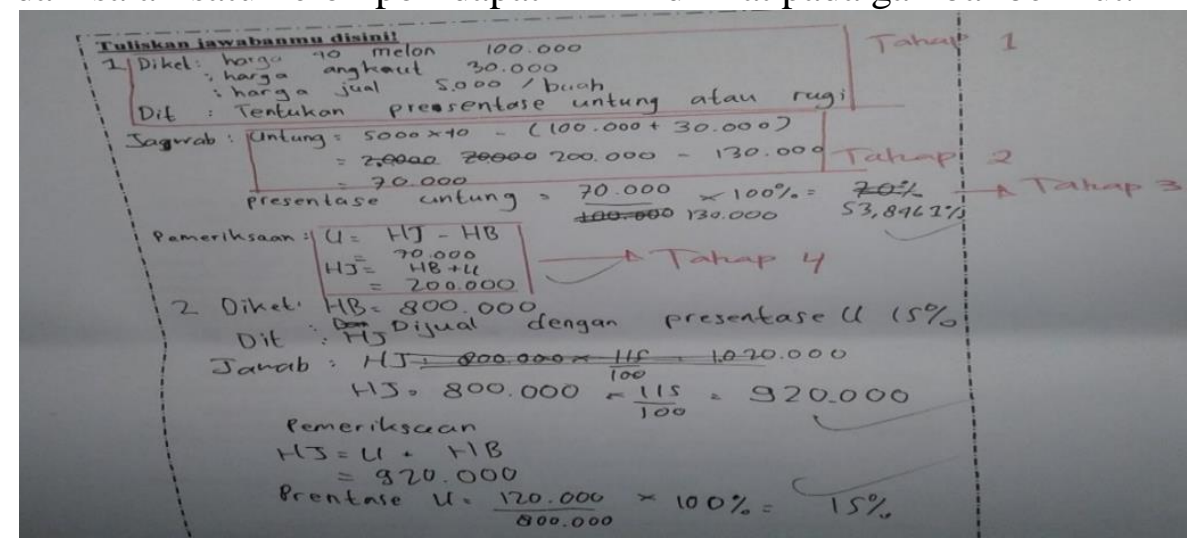

Gambar 2. Hasil Penyelesaian Masalah Kelas PBL

Dalam penyelesaian masalah tersebut, siswa sudah memenuhi indikator kemampuan pemecahan masalah matematis. Terlihat dari jawaban siswa pada nomor 1, pada tahap 1 siswa mampu memahami masalah dengan menuliskan apa yang diketahui dan apa yang ditanyakan. Kemudian, pada tahap ke-2 siswa merencanakan penyelesaian dengan mencari untung terlebih dahulu. Pada tahap ke-3 siswa melaksanakan rencana dengan menghitung peresentase untung. Terakhir, tahap ke-4 siswa melakukan pemeriksaan.

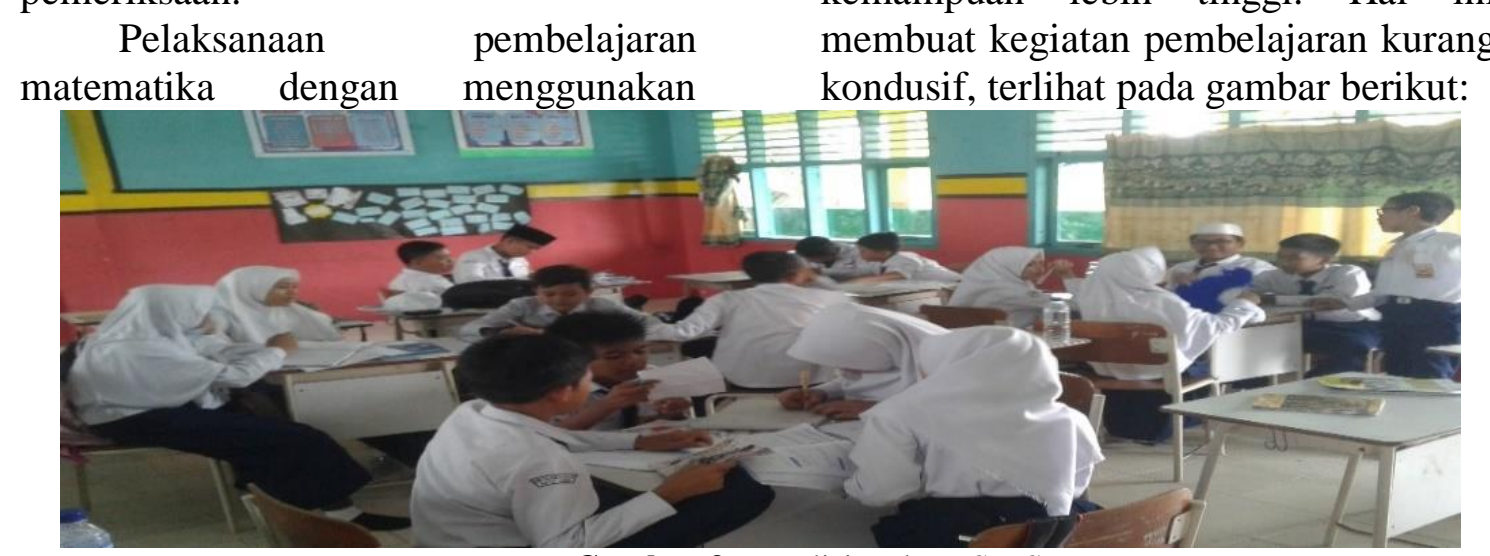

Gambar 3. Kondisi Kelas TS-TS

Karena siswa kurang aktif dan hanya mengandalkan temannya yang memiliki kemampuan lebih tinggi, hasil dalam penyelesaian masalah dari model TS-TS juga merupakan hal baru bagi kelas VII.2 di SMP Islam Al-Falah Jambi. Dalam pelaksanaan model pembelajaran TS-TS dua orang siswa tinggal di kelompok dan dua orang siswa bertamu ke kelompok lain. Dua orang yang tinggal bertugas memberikan informasi kepada tamu tentang hasil kelompoknya. Sedangkan yang bertamu bertugas mencatat hasil diskusi kelompok yang dikunjungi. Dalam pelaksanaan pembelajaran ini siswa kurang aktif dan hanya mengandalkan temannya yang memiliki kemampuan lebih tinggi. Hal ini membuat kegiatan pembelajaran kurang kondusif, terlihat pada gambar berikut

cam penyelesaian masalah dari

pelaksanaan model TS-TS kurang maksimal. Hal ini dapat dilihat pada penyelesaian masalah dari salah satu kelompok berikut: 


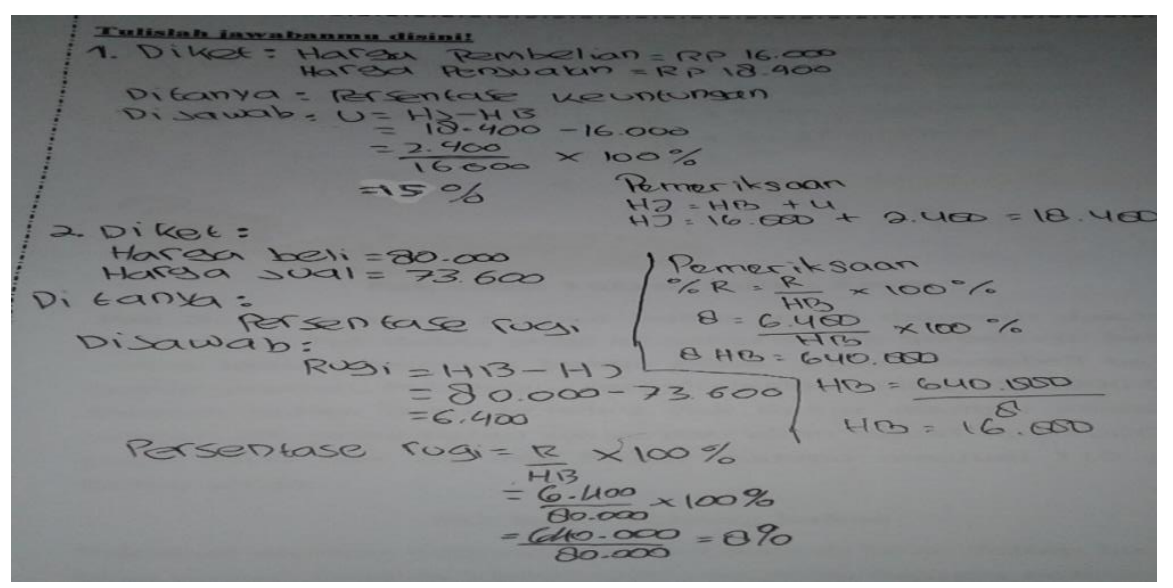

Gambar 4. Hasil Penyelesaian Masalah Kelas TS-TS

Hasil penyelesaian masalah dari salah satu kelompok tersebut sudah memenuhi indikator kemampuan pemecahan masalah matematis. Namun, dalam pengerjaan soal siswa tidak dapat menyelesaikan semua soal yang diberikan oleh guru. Dalam LKS terdapat lima soal, tetapi hanya dua soal yang dapat diselesaikan oleh salah satu kelompok tersebut. Maka, dalam pembelajaran TS-TS membutuhkan waktu yang cukup lama.
Dalam pelaksanaan model pembelajaran konvensional merupakan hal yang sudah biasa bagi kelas VII.4 di SMP Islam Al-Falah Jambi. Kegiatan pembelajaran di kelas VII.4 cukup kondusif. Namun, siswa cenderung diam dan tidak mau bertanya jika mereka kurang mengerti pada soal yang diberikan oleh guru. Kondisi kelas Konvensional dapat dilihat pada gambar berikut:

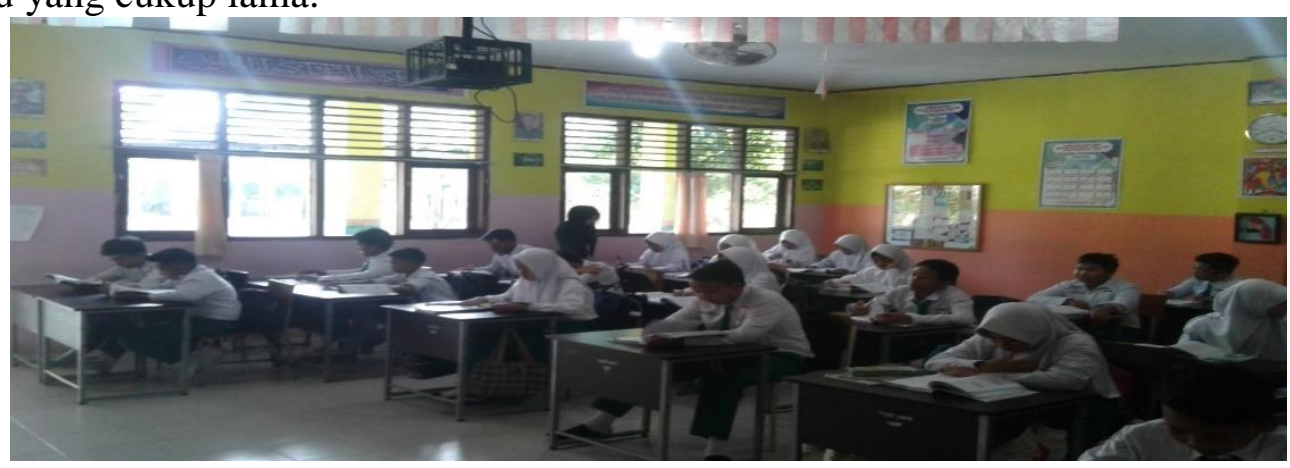

Gambar 5. Kondisi Kelas Konvensional

Perbedaan peningkatan kemampuan pemecahan masalah matematis siswa yang memperoleh model pembelajaran TS-TS dan model pembelajaran PBL yang terjadi disebabkan oleh waktu yang dibutuhkan pada kelas TS-TS cenderung lebih lama karena dalam proses pembelajaran mereka harus menyelesaikan masalah yang diberikan oleh guru bersama kelompoknya yang biasanya belum selesai kemudian harus bertamu ke kelompok lain. Pada kelas PBL siswa aktif dalam kelompok untuk mencapai tujuan yaitu memecahkan masalah pada materi aritmatika sosial sehingga mempengaruhi waktu dalam proses belajar.

Perbedaan peningkatan
kemampuan pemecahan masalah 


\section{$\pi$ (Phi)}

matematis siswa yang memperoleh model pembelajaran PBL dan model pembelajaran konvensional. Ini terjadi karena siswa yang mempeloreh model pembelajaran PBL dilatih untuk mengembangkan kemampuan pemecahan masalah matematisnya melalui lembar kerja yang diberikan memuat indikator-indikator kemampuan pemecahan masalah matematis. Dalam pembelajaran PBL siswa memiliki kemampuan pengetahuannya sendiri melalui aktivitas belajar.

Selanjutnya, tidak terdapat perbedaan peningkatan kemampuan pemecahan masalah matematis siswa yang memperoleh model pembelajaran TS-TS dan model pembelajaran konvensional. Hal ini dikarenakan pada proses pembelajaran di kelas TS-TS membutuhkan waktu yang cukup lama sedangkan pembelajaran pada kelas konvensional tidak diberi perlakuan dan siswa kurang aktif dalam belajar.

\section{SIMPULAN DAN SARAN}

Berdasarkan pengujian hipotesis yang dilakukan dengan uji Kruskal Wallis $H$ dan uji Post Hoc diperoleh kesimpulan sebagai berikut:

1. Terdapat perbedaan peningkatan kemampuan pemecahan masalah matematis siswa yang memperoleh model pembelajaran kooperatif tipe Two Stay-Two Stray (TS-TS), model pembelajaran Problem Based Learning (PBL), dan model pembelajaran konvensional.

2. Terdapat perbedaan peningkatan kemampuan pemecahan masalah matematis siswa yang memperoleh model pembelajaran kooperatif tipe Two Stay-Two Stray (TS-TS)dan model pembelajaran Problem Based Learning (PBL).

3. Tidak terdapat perbedaan peningkatan kemampuan pemecahan masalah matematis siswa yang memperoleh model pembelajaran kooperatif tipe Two Stay-Two Stray (TS-TS) dan model pembelajaran konvensional.

4. Terdapat perbedaan peningkatan kemampuan pemecahan masalah matematis siswa yang memperoleh model pembelajaran Problem Based Learning (PBL) dan model pembelajaran konvensional.

\section{DAFTAR PUSTAKA}

Aunurrahman. 2011. Belajar dan Pembelajaran.Bandung: Alfabeta.

Defitriani, Eni. 2015. "Penerapan Pendekatan Differentiated Instruction (DI) Untuk Meningkatkan Kemampuan Koneksi dan Disposisi Matematis Siswa SMP”. Tesis. Bandung: Program Pascasarjana UPI Bandung.

Hendriana, H., Roehati. E. E. dan Sumarmo, U.2017. Hard Skills dan Soft Skills Matematik Siswa. Bandung: PT Refika Aditama.

Lestari, K.E. dan Yudhanegara, M.R. 2015. Penelitian Pendidikan Matematika. Bandung: Alfabeta.

Lestari, S.W. 2017. Hasil Belajar Matematika dengan Strategi Problem Based Learning dan Two Stay Two Stray Ditinjau Dari Motivasi Belajar Siswa Kelas VIII SMP 23 Surakarta, (Online).

Roebyanto, G. dan Harmini, S. 2017. Pemecahan Masalah Matematika. Bandung: PT Remaja Rosdakarya.

Shadiq, Fajar. 2014. Strategi Pemodelan Pada Pemecahan Masalah Matematika. Yogyakarta: Graha Ilmu.

Shoimin, Aris. 2014. 68 Model Pembelajaran Inovatif dalam Kurikulum 2013. Yogyakarta: ArRuzz Media. 
Solso, R. L., Maclin, O. H. dan Maclin, M.K. 2008. Psikologi Kognitif. Jakarta: Erlangga.

Suraji dan Sari, A. 2017. Penerapan Model Kooperatif Tipe Two StayTwo Stray (TSTS) dalam Upaya Meningkatkan Kemampuan Pemecahan Masalah Matematis Siswa SD, (Online), Vol. 3, No.2. 